\title{
Extracting the Commons
}

\author{
Johanna Dahlin and Martin Fredriksson \\ Journal Article
}

\section{Tweet}

N.B.: When citing this work, cite the original article.

This is a postprint version of an article published in:

Johanna Dahlin and Martin Fredriksson, Extracting the Commons, Cultural Studies, 2017. 30(6), pp.1-24.

Cultural Studies is available online at informaworldTM:

http://dx.doi.org/dx.doi.org.e.bibl.liu.se/10.1080/09502386.2017.1303428

Copyright: Taylor \& Francis (Routledge): SSH Titles

http://www.routledge.com/

Postprint available at: Linköping University Electronic Press

http://urn.kb.se/resolve?urn=urn:nbn:se:liu:diva-135764

\section{H.U UNNGERSSIIES}




\title{
Extracting the Commons
}

Johanna Dahlin

Department for Studies of Social Change and Culture

Linköping University

johanna.dahlin@lilu.se

Martin Fredriksson

Department for Studies of Social Change and Culture

Linköping University

martin.fredriksson@liu.se

\begin{abstract}
This article investigates how resources that are perceived as common are turned into property through different interventions of extractivism, and how this provokes counter-activism from groups and actors who see their rights and living conditions threatened by the practices of extraction.
\end{abstract}

The article looks at how extraction is enacted through three distinct practices: prospecting, enclosure and unbundling, studied through three different cases. The cases involve resources that are material and immaterial, renewable as well as non-renewable, "natural" as well as manmade. Prospecting is exemplified by patenting of genetic resources and traditional knowledge, enclosure is exemplified by debates over copyright expansionism and information commons, and unbundling through conflicts over mining and gas extraction. The article draws on fieldwork involving interviews and participant observation with protesters at contested mining sites in Australia and with digital rights activists from across the world who protest against how the expansion of copyright limits public access to culture and information.

The article departs from an understanding of "commons" not as an open-access resource, but as a resource shared by a group of people, often subjected to particular social norms that regulate how it can be used. Enclosure and extraction are both social processes, dependent on recognising some and downplaying or misrecognising other social relations when it comes to resources and processes of property creation. These processes are always, regardless of the particular resources at stake, cultural in the sense that the uses of the commons are regulated through cultural norms and contracts, but also that they carry profound cultural and social meanings for those who use them. Finally, the commonalities and heterogeneities of these protest movements are analysed as 'working in common', where the resistance to extraction in itself represents a process of commoning.

Key words: extraction, commons, information commons, property, prospecting, enclosure, unbundling, piracy, intellectual property, natural resources, mining, bioprospecting, multitude 


\section{Extracting the Commons}

In early November 2015 a harvest festival was organised on a farm outside Breeza in northwestern New South Wales, Australia. Breeza is located on the Liverpool Plains, rich black-soil farmland which produces two crops every year. On the surrounding fields the winter crops of wheat were ripe and ready for harvest. Yet, despite the name and the setting of the festival, there was not much focus on either harvest or agriculture. Instead, it was a rally against plans for a coal mine in the area. The festival attracted a diverse crowd of farmers, environmentalists and indigenous groups. The organisers estimate that 750 people visited the festival, which included workshops and plenary talks. The workshops focused on issues such as clean water, koala preservation and Aboriginal heritage. The farm vehicles and machinery had been moved out of their (huge!) shed which then functioned as a make-shift stage, on which the invited speakers, politicians, farmers and Aboriginal elders were all in agreement with one another: this is the wrong mine in the wrong place (as one of the festival slogans stated).

This article uses the Breeza Harvest Festival and the resistance to the coal mine on the Liverpool Plains as one of several cases to highlight different dimensions of the tension between commons and extraction. The extractive process is seen as a series of practices aimed at creating property out of resources that are in many cases commonly used. The concepts of commons and extraction can be seen as the point of departure for this article, which will analyse how these concepts interact in the extractive process in relation to counterstrategies to defend (common) resources from the threat of extraction. The discussion is structured around a series of cases, involving different kinds of resources, which exemplify how extraction, in our view, is enacted through three distinct practices: prospecting, enclosure and unbundling. Furthermore, the article also analyses counterpractices of commoning, which is defending existing commons or actively opening up new ones.

The article opens with a theoretical overview of the relationship between extraction and commons. This will be followed by three cases focusing on prospecting exemplified through patenting of genetic resources and traditional knowledge, enclosure exemplified through debates on copyright expansionism and information commons, and unbundling exemplified through conflicts over mining and gas extraction. Finally, we turn to a notion of 'working in common' and commoning as a resistance to extraction. This final section also discusses commonalities and heterogeneities of these protest movements, both between and within the different cases.

\section{Extraction and Commons}

Extraction is a form of resource appropriation, linked to what Veltmeyer \& Bowles (2014, p. 66) call 'the fundamental impulse of capitalism to enclose the commons'. Extraction in the sense we are concerned with here is a process of locating, acquiring and selling a resource, in other words it is a mode of accumulation closely associated with capitalism (Acosta 2103, p. 62). We will break this process down in three moments, or dimensions: prospecting, enclosure, unbundling, which will be discussed further in the following chapters. The notion of 
extractivism, which is also sometimes used, stresses the ideological connections between this form of resource use and capitalism. Extractivism is closely related to global inequalities, where the extraction of resources is fuelled by a demand in metropolitan centres distant from the location of the resource to be extracted, and where both the resource and the profit it generates tend to be exported. As Acosta again points out, extraction of natural resources has been closely associated with colonial and neo-colonial practices (or with 'plunder and appropriation' which is his more straightforward term) (Acosta 2013, p. 63). While our project focuses on rich, developed countries, the anti-extraction movements often highlight the colonial elements that exist in resource extraction within these countries, not least in respect to the indigenous population, as well as internal inequalities in domestic policies.

While the primary examples of extractive industries are oil and minerals, Acosta points out that extractivism is also present in other industries such as farming, forestry and fishing. In applying the concept in this way, Acosta directs attention to its inherent unsustainability meaning that 'renewable resources, such as forests or soil fertility, are becoming non-renewable' through the overexploitation that characterises extractivism (Acosta 2013, p. 62).

This enclosing or commodifying tendency of capitalism is at the centre of some thinking in political theory, which uses a terminology of commons almost metaphorically as both what is threatened by the advances of neoliberalism, and as a resistance to these advances. The most influential works in this tradition are perhaps the books by Hardt and Negri (2000, 2004, 2009), who argue that the commons were destroyed by the advent of private property (Arvanitakis 2012). This relies on a relatively loose definition of the concept of the commons as that which is free for everyone to enjoy (cf Arvanitakis 2012, p. 62).

A similar definition of commons underpins Garret Hardin's famous article 'The tragedy of the commons' from 1968, where he argues that natural resources that are at anyone's unregulated disposal will inevitably be exploited and exhausted when everyone tries to maximise their own share before the wells (literally) run dry. Although Hardin's thesis was never based on empirical evidence, and has since been thoroughly disproven, it has continued to have significant impact, largely due to how neatly it gives ideological support to the enclosing and commodifying tendencies of capitalism (Goldman 1997, Arvanitakis 2012).

Both Hardin's and Hardt and Negri's work relies on a definition of commons as a resource freely available to anyone. In contrast, the research tradition foregrounded by Ellinor Ostrom qualifies the concept of the commons (sometimes also termed 'institutions for collective action') by drawing attention to the fact that the commons are in fact not at everyone's unregulated disposal, but there are specific norms regulating their use. As several scholars have noted, the idea of the tragedy of the commons conflates commons and open access regimes (cf Ostrom 1999, Bollier 2002, p. 20, Fennel 2011, p. 12). If the open access regime denotes resources open to everyone without restriction, there is a 'social infrastructure' involved in the management of the commons (Bollier 2002, p. 20). The distinction between commons and open access resources is both critical and easily blurred. To view nature as a commons, with individual and social regulations and restraints, is quite different from viewing it as an open 
access resource 'free-for-all' (Bollier 2002, p. 63) and it can be argued that it is the open access regime that allows commodification and exploitation.

\section{Prospecting and Property Creation}

As we saw above, a precondition for extraction is that the resource in question can be located, and separated. This part of the process is usually referred to as prospecting. Since this can also be seen as separation of a resource from its context, we will call this kind of decontextualisation unbundling, and will return to this term below.

We exemplify this part of the process with bioprospecting (sometimes referred to as biopiracy) - i.e. the patenting of genetic material and traditionally held knowledge on how to use it. Bioprospecting is a practice that extracts and commodifies both material resources (the biological substances) and immaterial resources (the knowledge on how to use them), which is often related to a spatially ordered structure of power (neo-colonialism). According to conventional criteria within Western intellectual property law, traditional knowledge and indigenous use of medical plants are considered to be neither new nor innovative and thus not qualified for protection as intellectual property. However, when Western companies take those substances to the lab, test them and turn them into pharmaceutical drugs they become patentable which means that international property law becomes a mechanism that denies traditional owners the rights to that knowledge (Oguamanam 2006).

Bioprospecting is an extractive practice in which propertisation decontextualises resources, as certain plants and the particular knowledge on how to use them are taken out of their social and cultural context (Posey 2002). Bioprospecting can be understood as a kind of extractivism which, by focusing on the economic value of a resource, undermines other values inherent in the relationship with the natural world. In many cases, these 'values are an integral part of people’s cultural identity' (Oguamanam 2006, p. 9).

Prospecting is dependent on the resource in question being defined as an open access resource. The regulation of bioprospecting is a good example of the difference between a regulated commons and a free for all open source resource. The traditional knowledge held by local, indigenous communities is often regulated as a commons where certain rules on how it can be transmitted and used exist among the local community. When the resource is patented and privatised these norms are replaced by another regulatory system provided by Western property rights. A precondition for that appropriation is however that the resources are there for the taking in the first place. In this case, seeing something as a common resource can actually enable such appropriation. Up until the passing of the UN Convention on Biodiversity (CBD) in 1992, genetic resources had been defined as a 'common heritage of mankind', making them up for grabs for multinational biotech companies. Such a definition disregards, despite its name, the commons dimension of the resource and makes it open access. As an attempt to stop exploitative acts of bioprospecting the convention acknowledges sovereign states the rights over genetic resources found within their borders (Hemmungs Wirtén 2008, p. 71). In this case the national appropriation of such resources is used as a means to stifle more exploitative forms 
of privatisation as it lets the states set the conditions under which the resources may be accessed by commercial actors.

If prospecting is dependent on the resource, the creation of private property/a commodity is not in the resource itself, but in the process. Extractive practices involve processing resources and turning them into commodities. This is an example of John Locke's definition of property as the product of labour, which has become a philosophical cornerstone for the liberal understanding of property rights in general and intellectual property in particular:

[E]very man has a 'property' in his own 'person'. This no body has any right to but himself. The 'labour' of his body, and the 'work' of his hands, we may say, are properly his. Whatsoever, then, he removes out of the state that Nature hath provided and left it in, he hath mixed his Labour with it, and joined to it something that is his own, and thereby makes it his property (Locke 2000[1690]).

The view that labour is the foundation of property rests on the assumption that the resource in question belonged to no one, and the common law understanding was that all land was held in common by humanity (Galloway 2012, writing from an English/Australian perspective). This logic underpinned colonialism where territories not claimed by any European state were up for grabs, and as we have seen it still lingers in the practice of prospecting, be it for metals or bioprospecting which sees both genetic material and local knowledge on how to use it as open access resources available for appropriation. This logic sees the act of extraction as in itself creating property.

The views of property discussed so far have not taken into account its relational dimension. In contrast, the anthropological research tradition on property departs from an understanding of property as embedded and based in social relations. As Chris Hann (1998) points out, these relations do not only exist between humans, things (tangible and intangible) are also parts of these relations of property. This view of property is focused on the 'relations between society's members with respect to valuables [that] are given form and significance' (von BendaBeckmann et al 2006, p. 14). These relations have three major elements: the social units that can hold property rights and obligations, the construction of valuables as property objects, and the different sets of rights and obligations social units may have with respect to such objects. All three are set into time and space (ibid, p. 15). Viewing property as rights and focusing on different forms of relations highlights the similarities between land and immaterial goods, since rights of usage in both instances can be just as important as ownership rights.

Seeing property as embedded in social relations means that different types of property are difficult to make out from one another. ${ }^{1}$ Hardin's 'tragedy of the commons', mentioned earlier, only makes sense in relation to the private cows that are responsible for the overgrazing. Property, thus, is seen not as a thing, but as a package and the metaphor of 'bundle of rights' is

\footnotetext{
${ }^{1}$ In the Western tradition, four major types of property are distinguished: open access, which can be seen as a form of non-property, common property, state property, and private property. These are associated with a number of assumptions, which in Western traditions of economic theory have favoured private property as the most desirable and efficient.
} 
often used, where property is seen as a category made up of many 'sticks' representing different property rights (cf. von Benda-Beckmann et al 2006). ${ }^{2}$

Using the same metaphor, Kate Galloway discusses how property rights in land have become 'unbundled' in the Australian context. There, the common law provided that a land owner owned more than the mere surface of the soil ('up to heaven and down to hell') and that land included minerals, subsurface, sky, water and vegetation. Subsequent legislation has however excluded, unbundled, for instance minerals and water from this land bundle (Galloway 2012, p. 78), creating parallel subjects of property rights.

\section{Commons and Enclosure: Regulating to Preserve Openness}

Jay Emerson, a young man in a black hoodie, leans across the table and raises his voice, partly to make himself heard over the background noise and partly to emphasise the gravity of the situation: 'To let government regulate the internet - more censorship basically - is allowing them to take away the future of humanity'. He is sitting at a crowded Starbucks next to Zuccotti Park in New York, where the Occupy Wall Street protests first began in September 2011. By this point, April 2012, the protests are waning, but Jay still wants to be close to the site in case something happens. Jay has been there regularly to protest against global capitalism ever since the demonstrations started, but now we are talking about his work with the Pirate Party. Jay describes how his involvement with the New York Pirate Party grew out of a concern that strict copyright laws threaten the internet's potential to form a new kind of information commons: an arena for mutual and global exchange of culture and information that can contribute to a more democratic and enlightened society.

Six months later Christian Engström leans back in his armchair behind his desk in a spacious office overlooking Brussels. He is also talking about his work for the Pirate Party, but as a member of the European Parliament for the Swedish Pirate Party. He leafs through a short pamphlet he has written together with the party founder, Rick Falkvinge, which reflects concerns akin to Jay's:

The internet is the greatest thing that has happened to mankind since the printing press, and quite possibly a lot greater [...] And we have only seen the beginning. But at this moment of fantastic opportunity, copyright is putting obstacles in the way of creativity, and copyright enforcement threatens fundamental rights... (Engström and Falkvinge 2012, p. 7)

Both Jay Emerson and Christian Engström take part in a debate over digital piracy that basically concerns how to define culture and information: while copyright holders see cultural works as their immaterial property which is being stolen, ideologically driven file-sharers often regard file-sharing as an act of communication where culture and information are seen as common resources. These conflicts are deepened when the industry does not understand the strong values

\footnotetext{
${ }^{2}$ The metaphor is not new, it can be traced back to the $19^{\text {th }}$ century and Henry Maine, and it is used in other influential works on property (Hann 1998).
} 
attached to the resources at stake: when the extraction of a commodity is contrasted against the public access to a cultural heritage or even 'the future of humanity'.

Since the late 1990s the privatisation of intellectual resources has become the subject of a growing body of research (c.f. Betting 1996, Drahos 1997, Lessig 1999, 2001 \& 2008, Coombes 1998, McLeod 2001, Drahos \& Braithwaite 2002, Vaidyanathan 2004, Hemmungs Wirtén 2004 \& 2008, Benkler 2006, Gillespie 2007). A cornerstone here is James Boyle’s extensive research on the 'Second Enclosure Movement' (Boyle 1997, 2003, 2008). Boyle discussed how intellectual property rights are used to privatise a growing range of previously common resources, from information and cultural heritage to traditional knowledge and genetic material (Boyle 1997). This point had been made by many other scholars, but Boyle added another aspect by comparing the tension between intellectual property and the public domain to the historical enclosure of agricultural land in England between the $15^{\text {th }}$ and $19^{\text {th }}$ centuries, when land areas that had been collectively used were gradually turned over to private landowners (Thompson 1963, Boyle 1997, 2003, 2008). While some historians see the enclosure of the commons as depriving poor people of their means of support, others see it as the introduction of more efficient means of managing farm land (Thompson 1963, Armstrong 1981). This process has become the subject of long standing debates over the best way to manage resources where collective use is contrasted against private ownership. By speaking of a second enclosure process, Boyle and others thus conceptualised the privatisation of culture and information through intellectual property as analogous to the enclosure of public space and natural resources.

Much commons research has pointed towards important commonalities between material and immaterial resources. Hess and Ostrom (2006) argue that around 1995 an information commons' movement emerged as an 'increased number of scholars found that the concept of the "commons" helped them to conceptualise new dilemmas they were observing with the rise of distributed digital information' (Hess and Ostrom 2006, p. 6, cf. Frischmann et al 2014). The idea of an information commons had a political impact in the copyright debates that emerged in the late 1990s. By comparing the tension between intellectual property and the public domain to the historical enclosure of agricultural land in England when speaking of a second enclosure process, Boyle and others thus conceptualised the privatisation of culture and information through intellectual property as analogous to the enclosure of public space and natural resources.

A big difference between information commons and environmental commons is that, unlike most material resources, intellectual resources are not depletable as such: in a digital age they are in fact infinitely reproducible. The idea of an information commons further undermines Hardin's thesis, which is hard to apply to immaterial resources. The catch is that it is hard to sell an infinitely reproducible resource, at least using conventional business models. That is why intellectual property rights impose a logic of scarcity on immaterial resources in order to make them commercially valuable. An aggressive use of intellectual property rights can thus be problematised as an act of extractivism making non-depletable resources depletable.

Today the debate focuses mainly on how the commons are under threat from a continuous process of enclosure where multinational companies privatise and commodify everything from water and land to traditional knowledge, culture and information. Arvanitakis speaks of a 
'frontier disposition' where capitalism in late modernity 'continues to identify new frontiers to commodify' [referens?]. When capitalism's need for expanding markets pushes the processes of privatisation to new levels, genes, organisms and information are increasingly privatised as intellectual property. As Bollier points out, enclosure 'threatens the environment by favouring short-term exploitation over long-term stewardship’ (Bollier 2002, p. 7).

Central to this commodification is the manufacturing of scarcity, which many writers argue is achieved through the enclosure of the commons (cf. Arvanitakis 2012, p. 72). Hardt and Negri (2004) have discussed the ambiguous relation between capitalism and the commons, where capitalism is inherently reliant on the commons to produce new commodifiable resources to ensure the constant economic expansion. This creates a dialectic double bind between capitalism and commons where the expansion of commodifiable resources relies on the expansion of new commons to exploit (Hardt and Negri 2004, Arvanitakis 2012). A contemporary example of this is the expansion of new business models for open source software (cf Jakobsson 2012, Jakobsson \& Stiernstedt 2012).

Parallel to this growing criticism from academics, a number of organisations and movements have also taken stands against copyright expansionism. Organisations such as Electronic Frontiers Foundation, La Quadrature de net and the Pirate Party have tried to draw attention to how copyright impedes free speech and public access to shared human culture. Lynn Spender points out that the pirates' 'valuing of the commons is parallel to the desire of many academics, software developers, public interest groups and librarians who are part of an 'information commons' movement' (Spender 2009, p. 151). That the pirates, the professors and the librarians are closing ranks around the protection of the commons against the threat of enclosure might be a response against the expansion of both the scope, and jurisdiction of intellectual property regimes that has taken place since the 1990s. As Christine Schweiedles and Sasha ConstanzaChock attest, 'the enclosure of knowledge encroaches further into all spheres of life', forcing different protest movements to 'increasingly integrate intellectual property resistance into their agenda' (Schweiedles and Constanza-Chock 2009, p. 23). This could be regarded as a mainstreaming of intellectual property issues on both sides of the fence: while intellectual property rights are included in an increasingly wide range of sectors, and more and more kinds of resources are defined as intellectual property, different social movements are forced to take a stand on issues related to intellectual property (cf. Halbert 2005). To counter the expansion of intellectual property rights 'commons based alternatives to IPRs' are also becoming more widespread, which we can see not least in open source, hacker or pirate movements (Schweiedles and Constanza-Chock 2009, p. 23).

Criticism against copyright does not have to rest on an anti-capitalist position. The abuse of intellectual property rights can also represent a threat to free market ideals and new business models. Christian Engström, for instance, initially jointed the Pirate Party to protest against the proposed introduction of software patents, which he saw as a threat to the new generation of IT companies. While working in the European Parliament he soon came to the conclusion that outdated intellectual property industries set the agenda in Brussels while emerging businesses with different needs were disregarded: 
the interests of the lobbyists rule, which are to support old business, which always happens at the expense of the new ... so EU represents an economic conservatism and a hostility towards the market which is harmful for the economy.

Many other Pirate Party members also talk about file-sharing as an important tool when initiating dialogue between people from different parts of the world as it (ideally) gives everyone equal access to culture and information. Here the process of enclosure through copyright expansionism is seen as a threat to free culture and open access to knowledge that new technologies enable (Fredriksson 2015a). Some see the internet as a medium of education and embrace file-sharing as a way of sharing and distributing knowledge. Jay Emerson expressed this enlightenment ethos when he talked about how he, while in college, suddenly realised that not only film and music but also textbooks and academic literature could be distributed and accessed through sites like The Pirate Bay:

I was thinking to myself. These books ... The whole purpose of the university back in the days was to send your kids off to it because that's where they had the libraries, the education, the expertise. That is no longer the case ... everybody should have access to the education and the knowledge of all those books . . . it's a humanitarian effort to get that out there.

In many regards the Pirate Party draws on an ideological and cultural heritage from the hacker and open source movement, which is characterised by strong norms on how to share information and data. The anthropologist Christopher Kelty describes the hacker community as a 'recursive public': 'a group constituted by a shared profound concern for the technical and legal conditions of possibility for their own association' (Kelty 2005, p. 185). This is a kind of extraordinarily self-reflexive public sphere that is fundamentally concerned with protecting, developing and discussing the very norms and structures that uphold it. The most obvious expression of this might be the central position that open source and Creative Commons take in this community, not only as technological and legal methods but also as norms that regulate the circulation of information (Kelty 2008, p. 298).

Few pirates argue for a total abolishment of copyright but all of them agree that culture and information should, in one way or another, be less restricted by limitations imposed by intellectual property rights. The fundamental principle is that culture and information should be shared, but they can be shared in many different ways. As the example of bioprospecting shows, unrestricted open access regimes might also expose the resources to undesired commodification. Within the open source, or 'copyleft', movement this problem has been solved through the so called General Public License: a copyright licence stating that the licensed code is free for anyone to use but that also applies to any programs that incorporate that code effectively preventing an open resource from ever being propertised (Bollier 2002, p. 28).

Intentionally or unintentionally, this ethos of unrestricted distribution challenges the construction of intellectual property by releasing cultural works from the logic of scarcity that underpins the construction of culture as a commodity. Although the resource as such is inexhaustible many copyright owners, on the other hand, would argue that open source regimes 
exhaust the economic value of the work which relies on that logic of scarcity. Many artists take a stand against piracy and argue that it denies them the right to their labour, and the property it creates, which is taken for granted by any other profession.

Not all file-sharers agree that the resources should be free to circulate in any possible way. Most P2P communities have certain rights and obligations associated with how those resources can be used. Alongside open pirate networks like The Pirate Bay there is a wide range of closed and specialised file sharing communities that are more similar to traditional commons. These often promote 'voluntary' property rights regimes, for instance by restricting what kind of material is to be distributed in the communities. Many such file sharing networks ration how much material a member can download based on how much s/he has contributed to the community, and artists who contribute their own original works are sometimes rewarded with extra quotas. Even though these communities disregard copyright they still impose their own rules of exchange which can be much more effective than any formal and universal system of property rights. The digital files that circulate in such a forum are not intellectual property as they belong to the community, but they are still attributed value according to an internal economy. The rules of exchange that apply here may also, just like copyright, construct an artificial scarcity to ensure that people contribute to the common pool of resources and not just consume without giving something back. This is a technique of governance of an information commons aimed at maintaining its continuous growth. While the ideology of piracy questions the propertisation of culture and information, the practices of piracy can, in some cases, also construct and impose their own internal economies and artificial systems of scarcity (Bodó 2014, Arvanitakis and Fredriksson 2016).

\section{Unbundling land - Breeza Harvest Festival}

In Breeza, where we began this article, the proposed mine against which the harvest festival protested, is being developed by Shenhua, a Chinese state-owned mining company. The Watermark, which is the mine's working name, would be a thirty-five square-kilometre opencut coal mine. It would comprise three open-cut pits, plus associated infrastructure, to mine up to ten million tonnes of coal per year for thirty years. Shenhua assures that the measures that will be taken to reduce the impact on environment and society are substantial, promising no disturbance of the 'alluvial black soil Liverpool Plains', Breeza State Forest, or Mt Watermark. According to the company, the project will have a 150-meter buffer between the active mining area and this famous black soil, and the groundwater regime will be protected by a horizontal barrier of natural material putting at least 900 meters between the active mining areas and 'the highly productive Gunnedah Formation aquifer' (Shenhua Watermark).

This aquifer is one of the main issues at stake. One of the participating organisations, Front Line Action on Coal, describes the 900-meter distance between the mine and aquifer as insufficient. In outlining their concerns they state that the groundwater system is the largest within the Murray Darling Basin, and call the system 'extremely complex and unique'. Referring to the Independent Expert Scientific Committee (IESC), they say that there is 'a knowledge gap of how this groundwater alluvium is directly connected to the coal seams being ripped out by Shenhua' (Front Line Action on Coal 2015).

In addition to water, festival host Andrew Pursehouse also outlines other concerns: 
It's not just the water issue and potential damages to the aquifer, it's the salt and the dust on 270 degrees around it, what that can do to our agricultural products, the koalas, the Aboriginal heritage (Daley 2015).

The farms themselves are the direct result of an enclosure process. (Others, of course, would say the land was stolen from the indigenous population.) During the British colonisation of Australia, land was claimed and privatised, ignoring the previous land use of the indigenous population. The claims were then turned into farms, fenced off and surrounded by a strong 'no trespassing' ethos. Aboriginal groups were denied access to their traditional lands, means of livelihood and sacred places. But, at least many sacred places survived. Jane Delaney-John, CEO of the Red Chief Land Council, phrased it like this: 'Sacred places have coexisted with agriculture. They can't survive with three gigantic pits gouging and excavating the land' (Morton 2015).

The threat of extraction is enclosure taken one step further. Although there are elements of extractivism to some farming practices, such as excessive irrigation leading to salinity and soil degradation, the proposed mine is on a different scale. Most importantly, as the centrality of the aquifer demonstrates, it threatens another common that land enclosure did not, the water. And the solution to the threat of extraction is an appeal to the common. Extraction is presented as a threat to the food produced by the land, as a threat to the koalas living on the land, and as a threat to the water. Food, biodiversity and water are essential common goods, and the koala, one might add, is of course an iconic Australian symbol that can be pitted against the foreign extractive company. Australia, it is often said, is the driest continent and the moisture of the black soil on these plains is one of their key assets.

Important within this context is also the Gomeroi/Gamilaraay ${ }^{3}$ Aboriginal heritage. During the speeches and workshops at the harvest festival, Aboriginal elders talked about the sacred places threatened by the planned Shenhua mine, and those already destroyed by Whitehaven's Maules Creek mine some 100 kilometres further north. Most significantly, the mine poses a threat to grinding grooves, sites where Aboriginal people traditionally sharpen their stone axe heads, causing indentations in the rock. 'This is our war memorial. This is our Gallipoli' ${ }^{4}$ as one elder put it during the workshop, a statement, which was repeated in many news items and webpages as well. The significance of Aboriginal heritage is not only put forward by Aboriginal elders themselves, but farmers and politicians alike stress the significance of the grinding grooves threatened by the mine, and the former MP for New England (where Breeza is located) Tony Windsor even says that 'it is Aboriginal heritage that will stop this mine'. While the Aborigines may be seen as a special interest group, the universal significance of this heritage is stressed along with its particularity. The traditional custodians of this heritage appeal to the universal values of heritage as a common: 'this is your heritage too' as it is articulated by the elders during the workshop.

\footnotetext{
${ }^{3}$ The name of the local Aboriginal people in this area was earlier written Kamilaroi. Since the sounds of that language do not exactly match the sounds of English, there are several alternative spellings with Gomeroi or Gamilaraay being the most common today.

${ }^{4}$ The Gallipoli peninsula in Turkey was the site of battles during WWI where in 1915 Australian troops sustained huge losses. Gallipoli has since gained almost mythical proportions in the Australian national imagination, and is a frequent site of pilgrimage for Australians.
} 
Since Aboriginal heritage is protected by Australian law, the relationship Aborigines have to the land is legally recognised, and this is a relation to the land that should influence decisions on industrial development. Shenhua and any other companies engaged in extraction need to take Aboriginal heritage into account. In a story published in January 2015 by ABC, Shenhua's project manager Paul Jackson presented the following proposal for dealing with the grinding groves:

Project Manager Paul Jackson said Shenhua proposes to move the rocks the Grooves are on, and put them back in the same location when the mining pit is rehabilitated, in 17 years.

'We've done significant geotechnical testing around the site, and the rocks are essentially floating rocks,' he said.

'They're not bedrock and they can be picked up as a whole in situ and we can quiet [sic] confidently move it [sic] safely to an area which could be set aside as a keeping place'. (ABC 2015)

The proposal to remove the site was disapprovingly discussed during the harvest festival. The idea to separate the site from the surrounding landscape is abhorred by the Aboriginal representatives speaking at the workshop. 'To remove the site is to destroy it', Jane DelaneyJohn said at the festival. 'They don't use the word destruction, they use the word removal. Removal is very familiar to the community.' Removal resonates with the Aboriginal children who for decades were systematically and forcibly removed from their families - a policy only ended in the 1970s - and who are now known as the Stolen Generations. In a Media Release from Gomeroi Traditional Custodians, signed by the Aboriginal elder Dolly Talbot, another speaker at the harvest festival, the idea to remove the grinding groves is strongly opposed:

Mr Jackson's statements suggest some kind of technical feat will be performed in 'gently moving the sacred grinding grooves out of the way while they undertake mining only to return them unharmed back in their place in several years to come'. Anyone that sees the Hunter and Whitehaven and Boggabri open cut mining activities knows how ridiculous this statement is.

Shenhua failed to tell the public that they intend to cut the grinding grooves up into pieces because the grinding groove sites are so large they can't be moved as one whole piece.

The truth is that Shenhua wants to carve them up - like a jigsaw puzzle forever destroying them. The aquifer providing the water which keeps the grinding grooves in their state will also be destroyed and the landscape Shenhua want to return the grooves pieces to will be forever changed and the meaning and purpose of the area lost. How can you declare smashed grinding grooves is not destruction? (FLAC 2015) 
As the release goes on, the idea to move the site is presented as one 'lost in translation', where the Chinese company has failed to understand the local and geographical significance of the sites. The Liverpool Plains Alliance quotes Desley Matthews, on the same subject:

In our culture, that is a sacred site, where they are, so if they move those Grinding Grooves out of situ, there's no more connect to that area with them. The sacred connection, the spiritual connection, is gone. It's not what we do. And [Shenhua] don't get that. (LPA 2015)

The idea to separate the land from the surrounding landscape is an example of unbundling, where the land is broken up into its constituent parts, rather than regarded as a unified whole. By proposing to remove the site, Shenhua acknowledges the value of the site and the Gomeroi people's relationship to it, but they fail to recognise how this site is related to the landscape as sacred in itself. And, indeed, if they did recognise this relation, mining might not be possible. Misrecognition, deliberate or not, in this way becomes a prerequisite for extraction when dealing with cultural legacies such as this one.

The one property relation that is recognised in this case is that of unbundled private property of land. Shenhua has indeed bought the land on which it plans to establish the mine. It is thus legally recognised private property. By these acquisitions, it circumvents one of the conflict areas that can be present in mining activities due to the two contradictory property regimes at work here. As Galloway (2012) points out, the unbundling of land rights to exclude for instance minerals has led to competing private property regimes. There is a conflict between the private property of land, and the private property in minerals. The influential lobby organisation Lock the Gate Inc, which is one of the organisations in the Liverpool Plains Alliance, uses private property and the right to exclude others from your property as a basis to fight coal and gas extraction in Australia. However, the unbundling of land and minerals from other resources is key to the resistance to the project. It is primarily the risks to the water that sparked the resistance among the farmers, because without a reliable water supply their land would become unworkable. The water is thus a threatened common. But the idea that a coal mine could be restricted to the limited area of the open-cut pit is also contested. Who wants to farm $150 \mathrm{~m}$ from an open-cut coal mine?

There is also a widespread opinion that the land should be used for agriculture, not coal. In this there is an appeal to a land's 'highest use' (Galloway 2012) as a moral basis for property. Food is foregrounded as a common good, not simply as an agricultural produce which forms the basis of the farmers' income.

The processes of property creation also involve rights and obligations in respect to property. Shenhua has bought the land, and selling is put forward as a right, the land is yours to own and sell. Speaking from the top of a minibus during the last day of the festival, Andrew Pursehouse assured the crowd, assembled for a photograph outside the fence bordering the land bought by Shenhua, that there is no animosity among the farmers to those of their neighbours who chose to sell. Not only were they offered many times the market value for their farms, but a refusal to sell might not be enough to stop the mine, and if this development goes on, the land will become worthless. 
The relations of private property are honoured through the buying of land. The law also requires that the relationship of Aboriginal people to their ancestral lands through cultural heritage be recognised, but the sentiment of the workshop clearly shows that there is a widespread belief that this is not the case. The lesson of the process is presented as 'The laws of Australia, and the laws of New South Wales, are not here to protect us'. Access to water and food is a right enshrined in, for example, international human rights documents, but as common resources, they have looser juridical protection than private property.

Shenhua has bought the land under which they propose to mine, and while the land has legally been compartmentalised, what goes on there will affect the surrounding area. As Galloway points out, the legal unbundling is clearly a fiction and she suggests land should be perceived as an ecological system to avoid compartmentalisation where different aspects are separated minerals, water, trees, animals - and that as a legal concept ownership of land should would be considered in terms of a unified whole. She also suggests that dominion and control be replaced by a more holistic and relational approach to the idea of private property (Galloway 2012, p. 80), which is very similar to the argument concerning the integrity of the sacred sites put forward by the Aboriginal groups.

\section{'Working in Common'}

In the cases outlined in this article, the resistance to enclosure and extraction is made up of diverse movements, and in this section we will discuss a way of understanding these heterogeneous movements as 'working in common'. Land and information appear to be widely different resources, but it needs to be pointed out that there is a material side to information since the hardware of the information society relies on the excessive extraction of minerals and other natural resources (cf. Reading 2015 on 'bringing the cloud down to earth'). Land, on the other hand, is not only a material but also a cultural and symbolic resource, which becomes obvious in the conflict over the grinding grooves as well as in the symbolic and religious values that indigenous communities often attribute to genetic resources that are being extracted through bioprospecting (Robinson 2014).

The extraction of those resources provokes similar reactions from a range of heterogeneous groups. While the Breeza case involves alliances between wealthy farmers, greenies and indigenous people, the protection of the information commons unites left wing anarchists with liberals from different organisational cultures. How can we understand these new alliances? We will turn to the concept of the multitude, as it is employed by Hardt and Negri, as a way to understand these movements. They define the multitude as 'internally different, multiple social subjects whose constitution and action is based not on identity or unity ... but on what it has in common' (Hardt and Negri 2004, p. 100). The multitude is ‘composed of innumerable internal differences that can never be reduced to a unity or a single identity - different cultures, races, ethnicities, genders and sexual orientations; different forms of labour ...' (Hardt and Negri 2004, p. xiv). Before returning to what the concept of the multitude can shed light on, we will outline the diverse movements in greater detail. 
The Breeza Harvest Festival was organised by the Liverpool Plains Alliance, an umbrella group for a number of organisations that are as diverse as the crowd at the festival. ${ }^{5}$ The Liverpool Plains are sometimes called 'Australia's food bowl', a designation which is prominently featured in the anti-mine campaign, and the rich farmland has produced equally rich farmers. The areas the farms and stations comprise are enormous. And many families own not one, but several farming stations. This is a well-established and politically well-connected group, and several informants tell us they have previously been reluctant to side with 'greenies, hippies and Aborigines'. But as the backstage lobbying has not yielded the desired results, they are now seeking new allies. Andrew Pursehouse has also been quoted in news reports admitting that the decision to enter into alliance with these groups was difficult,

Pursehouse says allying with environmentalists was a difficult decision for the farmers. There were vigorous discussions at CCAG meetings. Some members opposed any public alliance. Others felt they had no choice.

'We laid down some protocols for us to be part of this. This campaign is purely focused on coal mining on the Liverpool Plains-it's not about all mining. And if there is any protesting, it'll be farmers that will lead the advance.' (Morton 2015)

Pursehouse contends that his father would probably 'turn in his grave' if he knew his son was sharing the stage with the Greens (ibid.). However, not only the farmers are apprehensive about the new alliance, but other groups are reluctant to side with the farmers. This is especially true for the Aborigines, where there is a deep-rooted mistrust as the farmers have been locking them out from their traditional lands. So deep is this mistrust, that many individuals and land councils have chosen to side with the miners, as a way to ensure that if mining is inevitable, indigenous people may as well try to maximise the benefit from it (Mercer et al. 2014). The indigenous scholar Marcia Langton is one of the most high-profile advocates of this approach, arguing that agreements with mining companies have had greater benefits for communities than government policies (Langton 2012). This also, of course, reflects a mistrust towards the 'greenies', suspecting them of only having a token interest in indigenous issues. The alliance between greenies/activists and Aborigines is also relatively new, in this region originating in the resistance to another nearby coal mine, and if the greenies are 'excited' to be working with the Aborigines, the farmers seem a bit more uncomfortable. The enclosure of the farms and turning Aboriginal land into private 'white' property has meant that Aboriginal people have been locked out from their sacred places. The gates locked them out, but this new alliance has seen them open, albeit tentatively. That not all mistrust of farmers is gone is evident during the workshop: 'Don't let the gates close on us again' as one speaker in the Gamilaraay workshop puts it.

At the festival however, the emphasis is on unity and the union seems largely happy, but tensions do surface over the course of the weekend. Talking to one of our informants a few days later, a self-identified 'greenie' married into an Aboriginal family, he was happy with the

\footnotetext{
${ }^{5}$ The Liverpool Plains Alliance is made up of Gomeroi/Gamilaraay Traditional Custodians, Caroona Coal Action Group, Liverpool Plains Youth, Breeza Action Group, SOS Liverpool Plains, The Wilderness Society, Lock the Gate Alliance, Land, Water, Future, 350.org Australia, Front Line Action on Coal (FLAC), and Our Land, Our Water, Our Future.
} 
festival. While there was some tension, there were also signs of genuine will to create this new alliance. It is too early to say what this new alliance will lead to, but he called it a 'historic moment' for the Aborigines to present their demands to the farmers about getting access to land for ceremonies, food gathering etc. Talking to some other 'greenies', they agreed that they had perhaps been a bit too happy to have the farmers on board, refraining from presenting certain demands or issues, but that they were slowly gaining confidence.

While the 'no trespass' ideology held by the farmers might be distant from the ethos of the commons, the new alliances require a shift towards emphasising the commons at stake for all parties concerned. The slogans of the Australian anti-coal and gas movement stress alternative uses of the land. They do not see the environment as an extractive resource. They are not interested in the coal or the gas, but in what the extraction of these resources might destroy.

The processes of property outlined above stressed three aspects. The diverse social units with rights and interests in the area affected by the proposed coal mine appeal to different values, and construct different resources as valuables. For Shenhua, the value is coal, for the farmers, food and water, and the traditional owners emphasise their heritage, water and the land as an integrated whole. Environmental groups foreground water, koala preservation, heritage and food ('can't eat coal' is another slogan). The process of creating a mine is the process of constructing coal as being more valuable than any of the other resources. The climate is yet another common good that environmental groups would stress as important in resisting coal mining, keeping coal in the ground is often presented as a key to keeping global warming below the two degree target recently agreed on at the Paris Climate talks. However, in the case of the Liverpool Plains, climate change plays a very minor role when it comes to the reasons that are put forward for opposing the mine.

Strange bedfellows can also be found in the Pirate Party. Jay, from the New York Pirate Party introduced earlier, is an anarchist activist in in his late 20s who has spent years on the front line at demonstrations. Christian, on the other hand, is a middle-aged man who has worked for a long time as an IT entrepreneur. He held minor political posts for the Swedish Liberal party before getting involved with the Pirate Party, and following the success of the Swedish Pirate Party in the 2009 election to the European Parliament, he took up a seat and became a professional politician in Brussels between 2009 and 2014. In spite of their different backgrounds and political outlooks, both of them are nevertheless working within the same political party, against something that can be called the enclosure of the information commons.

Even a specific organisation such as the Pirate Party attracts a wide array of actors. Mattias Bjernemalm, staffer for Amelia Andersdotter - the second Swedish Pirate Party Member of the European Parliament between 2010 and 2014 - describes the party as composed of three different organisational cultures: 'the business people, the association people and the swarm romantics'. If the business people refers to IT entrepreneurs such as Christian Engström and the association people mainly consists of people with a background in formalised gaming associations, then the swarm romantics come from the open-source side of the movement. Internationally the span is even wider, ranging from anarchist activists that can also be involved with organisations such as Occupy Wall Street or Anonymous, to party functionaries who try to build a formal party organisation and establish the Pirate Party as a respectable alternative for mainstream voters (Fredriksson Almqvist 2016, Fredriksson and Arvanitakis 2015). In some 
cases, such as in the American and German Pirate Parties, this has led to more or less serious conflicts over both ideological and organisational issues. Although some people have left the party in protest, the ones remaining tend to see these kinds of disagreements as secondary to their common resistance against copyright expansionism (Fredriksson Almqvist 2016).

In an analysis of the diversity and complexity of the Counter Globalisation Movement, James Arvanitakis relies on Hardt and Negri's concept of 'the multitude', defined as 'multiple singularities' that work 'in common' (Hardt and Negri 2004, Avanitakis 2012). In his work, Arvanitakis argues that a distinguishing feature of the Counter Globalisation Movement is that it works not only to defend existing commons, but to create new ones. This aligns well with Hardt and Negri's theory that the multitude creates 'the common that allows them to communicate and act together' by establishing arenas where diverse movements can coexist and interact (Hardt and Negri 2004, p. xv). The common produced by the multitude should however not be confused with the commons: rather than referring to commonly managed resources Hardt and Negri's common is a common ground for interaction and collaboration that can encompass large differences between the collaborating actors. The working in common is also working for commons. In this regard the commons is not just the object of the struggles we have studied, it is also a consequence of those struggles as they create new common ground for previously alienated groups and actors. In our case, the umbrella of the Liverpool Plains alliance is 'working in common' in the sense of working towards the same goal, unified by a common enemy. This common ground allows the different actors to interact, although they have different relations to the commons at stake, particularly since a significant goal of the landowners is to protect their private property against exploitation rather than to maintain a commons. It is not only a conflict between common and private, but between different forms of private property. In their struggle to protect their property, even the wealthy farmers have to align with other groups and acknowledge the role that their land plays as a common cultural or environmental heritage.

Their common denominator is that these actors respond to processes of propertisation undertaken without regard to how these resources are constructed as valuables in those local communities. The cases we have looked at expose the construction (or in the case of the farmers, dispossession) of private property as both contestable and complicated. Both the pirates and the protestors on the Liverpool Plains oppose the extraction and propertisation of certain resources as these processes threaten other values and resources. Just as the coal is secondary to the protestors, the water and farmland are secondary to the extracting company, but they are crucial to the communities that use them. However, regardless of which resource is emphasised, they cannot be fully separated.

\section{Conclusion}

Based on three empirical cases involving the resistance against extractivism of traditional knowledge, information and land, this article has analysed the extractive process as structured in three moments. First of all extractivism involves a moment of prospecting - of locating resources and turning them into property - which essentially concerns how property is made. 
This is maybe most striking in the case of bioprospecting: a form of extractivism that inherently exploits both natural and intellectual resources simultaneously. Bioprospecting and appropriation of genetic material and traditional knowledge points to the question of what can be property, and thus captures a core conflict in the examples raised here. Secondly, extraction also involves a moment of enclosure. This is for instance highlighted by the pirate party activists' resistance to restricting access to knowledge and information in the name of property rights. Finally, extraction is dependent on separation, or unbundling, of the 'bundle of rights' that makes up property. In separating resources from one another, the fundamental ways that they belong together are disregarded, but this prioritising of particular resources also means a misrecognition of social and cultural relations. The disruptive forces inherent in the process of unbundling are made blatantly clear in Shenhua's proposal to extract and move the Aboriginal grinding grove site, disregarding its relation to the land. Unbundling is thus a form of decontextualisation which allows for changes of how resources are managed and circulated without regard to how they have been managed by local communities.

All these examples point to the power and exploitation inherent in the process of constructing something as a piece of property, enclosing it and unbundling it from its original context. These processes provoke reactions from a multitude of groups that in different ways challenge extractivism and enclosure through acts of commoning: of maintaining existing commons or creating new ones. The digital pirates are the most obvious case of a movement that explicitly tries to create commons, or in some cases open access regimes, by making previously restricted resources free for anyone to access. While the farmers on the Liverpool Plains, on the other hand, are defending their own private land form being damaged by neighbouring mines they nevertheless relies on the value of the commons to create alliances with other groups, such as indigenous communities and environmentalists. In this regard they can be said to perform a kind of strategic commoning. Finally, all of these groups work in common to create a mutually shared ground of communication, enabling what Hard and Negri call the multitude.

\section{Acknowledgement}

We would like to thank all who contributed to the study as interlocutors. We would also like to thank Ingrid Mathews at Western Sydney University (WSU) for fieldwork assistance, the Institute for Culture and Society at WSU for hosting us during the fieldwork, and the editors, reviewers and colleagues at Linköping University for comments on the manuscript.

This work was supported by the Swedish Research Council and the Marie Skldowska Curie Actions under Grant E0633901

\section{Biographies}

Johanna Dahlin is postdoctoral fellow at the Department of Culture Studies (Tema Q), Linköping University, Sweden, where she is working with the project 'Commons and Commodities: Knowledge, Natural Resources and the Construction of Property'. Her principal research interests are heritage, resource use and social mobilisation. E-mail: johanna.dahlin@liu.se 
Martin Fredriksson is assistant professor and Marie Curie Fellow at the Department of Culture Studies (Tema Q), Linköping University. He has been visiting scholar at MIT and University of Western Sydney. He is currently conducting a project about 'Commons and Commodities: Knowledge, Natural Resources and the Construction of Property' funded by the Swedish Research Council. He has previously worked with the history of copyright in Sweden and with piracy as a social movement, conducting extensive studies of Pirate Parties in Europe, North America and Australia. E-mail: martin.fredriksson@liu.se

\section{Disclosure statement}

The authors declare no conflict of interest. 


\section{References}

ABC, 2015. Gomeroi artefacts to be preserved if mine approved: Shenhua. Avaliable from: http://www.abc.net.au/news/2014-12-31/gomeroi-artefacts-to-be-preserved-if-mineapproved3a-shenhua/5994314 [accessed 18 December 2015].

Acosta, A., 2013. Extractivism and neo extractivism: two sides of the same curse. In M. Lang \& D. Molerani eds. Beyond Development: Alternative Visions from Latin America. Amsterdam: Transnational Institute, 61-86.

Armstrong, A., 1981. The Influence of Demographic Factors on the Position of the Agricultural Labourer in England and Wales, c.1750-1914. The Agricultural History Review, 29, 71-82.

Arvanitakis, J., 2012. The Cultural Commons of Hope, Berlin: VDM.

Arvanitakis, J. and Fredriksson, M., 2016. Commons, Piracy and the Crisis of property, TripeC, 14(1), 132-144.

Benda-Beckmann, F. von, Benda-Beckmann, K. von and Wiber, M. G., eds., 2006. Changing Properties of Property. New York and Oxford: Berghahn Books.

Benkler, Y., 2006. The Wealth of Nations: How Social Production Transforms Markets and Freedom, New Haven: Yale University Press.

Bettig, R. V., 1996. Copyrighting Culture: The Political Economy of Intellectual Property. Boulder: Westview Press.

Bodó, B., 2014. Set the fox to watch the geese: Voluntary IP regimes in piratical file-sharing communities. In M. Bollier, D. 2002. Silent Theft: The Private Plunder of our Common Wealth. London and New York: Routledge.

Bollier, D., 2006. The Growth of the Commons Paradigm. In C. Hess and E. Ostrom eds. Understanding Knowledge as a Commons. Cambridge: MiT Press, 27-40.

Boyle, J., 1997. Shamans, Software, and Spleens: Law and the Construction of the Information Society. Cambridge and London: Harvard University Press.

Boyle, J., 2003. The Second Enclosure Movement and the Construction of the Public Domain. Law and Contemporary Problems. 66(33): 33-74.

Boyle, J., 2008. The Public Domain: Enclosing the Commons of the Mind. New Haven: Yale University Press.

Coombes, R., 1998. The cultural life of intellectual properties: authorship, appropriation, and the law, Durham: Duke University Press.

Daley, M., 2015. The perfect storm - Shenhua and the Liverpool Plains. Available from: http://aidanricketts.com/the-perfect-storm-shenhua-and-the-liverpool-plains/ [accessed 29 April 2016].

Drahos, P., 1997. Thinking strategically about intellectual property rights. Telecommunication Policy, 21(3), 201-211.

Drahos, P. with Braithwaite, J., 2002. Information Feudalism: Who Owns the Knowledge Economy?. New York: New Press.

Fennell, L. A., 2011. Ostrom's Law: Property Rights in the Commons. International Journal of the Commons 5(1), 9-27.

Fredriksson, M., 2012. Piracy, Globalisation and the Colonisation of the Commons. Global Media Journal: Australian Edition, 6(1).

Fredriksson, M., 2013. An Open Source Project for Politics: Visions of Democracy and Citizenship in American Pirate Parties. In J. Arvanitakis and I Matthews eds. The Citizen in the $21^{\text {st }}$ Century. Oxford: Inter Disciplinary Press, 201-213.

Fredriksson, M., 2014. Copyright Culture and Pirate Politics, Cultural Studies, Volume 28(56), 1022-1047.

Fredriksson, M., 2015a. The Pirate Party and the Politics of Communication. International Journal of Communication, 9. 909-924. Available from: http://ijoc.org/index.php/ijoc/article/view/3742/1339 [accessed 29 April 2016]. 
Fredriksson, M., 2015b. Pirates, Librarian and Open Source Capitalists: New Alliances in the Copyright Wars. In H. Porsdam ed. Copyrighting Creativity: Creative Values, Cultural Heritage Institutions and Systems of Intellectual Property. Farnham: Ashgate.

Fredriksson, M and Arvanitakis, J., eds., 2014. Piracy: Leakages from Modernity, Sacramento: Litwin Books.

Fredriksson, M and Arvanitakis, J., 2015. Piracy, Property and the Crisis of Democracy', Journal of eDdemocracy and Open Government. 7(1), 135-150. Available from: http://www.jedem.org/index.php/jedem/article/view/365 [accessed 29 April 2016]

Fredriksson Almqvist, M., 2016. Pirate politics between protest movement and the parliaments, Ephemera, $\quad 16 \quad$ (2), 97-114. Available http://www.ephemerajournal.org/sites/default/files/pdfs/contribution/16-2almqvist.pdf [accessed 08 August 2016].

Frischmann, B, M., Madison, M. J. and Strandburg, K. J., eds., 2014. Governing Knowledge Commons. Oxford: Oxford University Press.

Front Line Action on Coal, 2015. Preserving Gomeroi grinding grooves lost in translation, January 30, 2015. Available from: http://frontlineaction.org/grinding-grooves/ [accessed 18 December 2015].

Galloway, K., 2001. Landowners’ vs Miners’ Property Interests: The Unsustainability of Property as Dominion Alternative Law Journal. 37(2), 77-81.

Gillespie, T., 2007. Wired Shut: Copyright and the Shape of Digital Culture, Cambridge, MA: MIT Press.

Hann, C., 1998. Introduction: The Embeddedness of Property. In C. Hann ed. Property relations: Renewing the Anthropological Tradition. Cambridge: Cambridge University Press.

Halbert, D.J., 2005. Resisting Intellectual Property Law. New York: Routledge.

Hardin, G., 1968. The Tragedy of the Commons. Science, 162, 1243-1248.

Hardt, M. and Negri, A., 2004. Multitude: War and Democracy in the Age of Empire, New York: The Penguin Press.

Hemmungs Wirtén, E., 2004. No trespassing: Authorship, intellectual property rights, and the boundaries of globalization, Toronto: University of Toronto Press.

Hemmungs Wirtén, E., 2008. Terms of use: Negotiating the jungle of the intellectual commons. Toronto, Buffalo, London: University of Toronto Press.

Hess, C. and Ostrom, E., eds., 2006. Understanding Knowledge as a Commons. Cambridge: MiT Press.

Hyde, L., 2010. Common as Air: Revolution, Art and Ownership, New York: Farrar, Straus and Giroux.

Humphrey, C. and Verdery, K., 2004. Introduction: Raising Questions about Property. In C Humphrey and K Verdery (eds.) Property in Question: Value Transformation in the Global Economy. Berg Publishers.

Jakobsson, P., 2012. Öppenhetsindustrin, Örebro: Örebro universitet. Retrieved from http://oru.diva-portal.org/smash/get/diva2:482726/FULLTEXT02.pdf [accessed 29 April 2016].

Jakobsson, P., and Stiernstedt, F., 2012. Reinforcing Property by Strengthening the Commons: A New Media Policy Program? TripleC 10(1), 49-55.

Kelty, C., 2008. Two Bits: The Cultural Significance of Free Software. Durham: Duke University Press.

Langton, M., 2012. The Quiet Revolution: Indigenous People and the Resources Boom. ABC Boyer Lectures Retrieved from: http://www.abc.net.au/radionational/programs/boyerlectures/2012-boyer-lectures/4305696 [Accessed 26 May 2016]. 
Lessig, L., 1999. Code and other laws of cyberspace. New York: Basic Books.

Lessig, L., 2001. The future of ideas: The fate of the commons in a connected world, New York: Random House.

Lessig, L., 2008. Remix: Making Art and Commerce Thrive in the Hybrid Economy, New York: Penguin Press.

Liverpool Plains Alliance, 2015. Gomeroi Culture. Retrieved from: http://liverpoolplainsalliance.com/portfolio/gomeroiculture/ [Accessed 18 December 2015].

Locke, J., 1690/2000. Two Treatises on Government. Hamilton: McMaster University.

McLeod, K., 2001. Owning culture: Authorship, ownership and intellectual property, New York: Peter Lang.

Mercer, A., de Rijke, K. and Dressler, W., 2014. Silences in the Boom: Coal Seam Gas, Neoliberalizing Discourse, and the Future of Regional Australia. Journal of Political Ecology, 21, 292-302

Morton, T., 2015. Unlikely bedfellows on the Liverpool Plains. Retrieved from: http://www.abc.net.au/radionational/programs/scienceshow/unlikely-bedfellows-on-the-

liverpool-plains/6945164 [Accessed 18 December 2015].

Oguamanam, C., 2006. International Law and Indigenous Knowledge: Intellectual Property, Plant Biodiversity and Traditional Medicine, Toronto: University of Toronto Press.

Ostrom, E., 1990. Governing the Commons: The Evolution of Institutions for Collective Action, Cambridge: Cambridge University Press.

Reading, A and Notely, T., 2015. The Materiality of Globital Memory. Bringing the Cloud to Earth. Continuum, 29(4), 511-521.

Robinson, D., Drozdzewski, D. and Kiddell, L., 2014. You can’t Change our Ancestors without our Permission. In M. Fredriksson and J. Arvanitakis, Piracy: Leakages from Modernity, 56-75. Sacramento: Litwin Books.

Shenhua Watermark Environmental Impact Statement. Retrieved from: http://www.shenhuawatermark.com/html/Watermark/Environment/EIS/ProjectPlanningAn dRefinement/ [Accessed 18 December 2015]

Thompson, E. P., 1963/1991. The Making of the English Working Class, London: Penguin.

Vaidhyanathan, S., 2004. The Anarchist in the Library: How the Clash between Freedom and Control is Hacking the Real World and Crashing the System, New York: Basic Books.

Veltmeyer, H. and Bowles, P., 2014. Extractivist resistance: The case of the Enbridge oil pipeline project in Northern British Columbia. The Extractive Industries and Society, 1(1), 59-68. Retrieved from: http://doi.org/10.1016/j.exis.2014.02.002 [Accessed 29 April 2016]. 